\title{
Morphological evidence for phages in Xylella fastidiosa
} Jianchi Chen* and Edwin L Civerolo

Address: San Joaquin Valley Agricultural Sciences Center, Agricultural Research Services, United States Department of Agriculture, Parlier, California, 93648, USA

Email: Jianchi Chen* - jianchi.chen@ars.usda.gov; Edwin L Civerolo - edwin.civerolo@ars.usda.gov

* Corresponding author

Published: 6 June 2008

Virology Journal 2008, 5:75 doi:10.1186/1743-422X-5-75

This article is available from: http://www.virologyj.com/content/5/I/75

(c) 2008 Chen and Civerolo; licensee BioMed Central Ltd.

This is an Open Access article distributed under the terms of the Creative Commons Attribution License (http://creativecommons.org/licenses/by/2.0), which permits unrestricted use, distribution, and reproduction in any medium, provided the original work is properly cited.
Received: 17 April 2008

Accepted: 6 June 2008

\begin{abstract}
Presumptive phage particles associated with Xylella fastidiosa strain Temecula-I grown in PW broth were observed by transmission electron microscopy (TEM) in ultrathin sections of bacterial cellcontaining low speed centrifugation pellets and in partially purified preparations from $\mathrm{CsCl}$ equilibrium centrifugation density gradients. Ultrathin-sectioned cell pellets contained icosahedral particles of about $45 \mathrm{~nm}$ in diameter. Samples collected from $\mathrm{CsCl}$ density gradients revealed mostly non-tailed icosahedral but also tailed particles. The icosahedral particles could be divided into two types: a large type (about $45 \mathrm{~nm}$ ) and a small type (about $30 \mathrm{~nm}$ ). Filamentous phage-like particles $(17 \times 120$ to $6,300 \mathrm{~nm}$ ) were also observed. The presence of different types of phage-like particles resembling to those in several bacteriophage families provides new physical evidence, in addition to $X$. fastidiosa genomic information, that $X$. fastidiosa possesses active phages. This is the first report of phage particles released in $X$. fastidiosa cultures.
\end{abstract}

\section{Findings}

Xylella fastidiosa [1] is a Gram negative plant pathogen causing many economically important diseases including Pierce's disease (PD) of grapevine, almond leaf scorch disease and citrus variegated chlorosis disease. Because of nutritional fastidiousness, many biological aspects of the bacterium including the occurrence of phages are difficult to study. Analyses of whole genome sequences of $X$. fastidosa strains identified many prophage sequences [2-5], including putative Siphoviridae [2,4], Podoviridae [6] and Inoviridae [3] phages. Yet, physical evidence for the presence of phage particles in X. fastidiosa is very limited. Lauzon and Miller [7] reported the association of particles resembling phages in the families Microviridae and Podoviridae with $X$. fastidiosa. However, only limited details regarding the origin(s) or nature of these particles were provided. Chen et al. [6] reported a phage DNA sequence of $547 \mathrm{bp}$ from the genome of a PD strain isolated in Flor- ida. The sequence shared high similarity to that of an integrase gene in the Podoviridae phage family. Interestingly, this sequence is absent in the whole genome sequence of a California PD strain Temecula-1, but is present in other California PD strains. In this paper, we report our observations of presumptive phage particles in a X. fastidios $\mathrm{PD}$ strain through transmission electron microscopy (TEM).

Phage observations were first made with intact bacterial cells. X. fastidosa strain Temecula- 1 was cultured in $30 \mathrm{ml}$ of PW broth medium [8] for 30 days at 28 C. Before bacterial cell collection, a loop of bacterial culture was streaked on PW plate and incubated at $28 \mathrm{C}$ to check for possible contamination based on culture characteristics (slow growing opalescent colonies with entire smooth margin) as well as PCR [9]. Bacterial cells were then collected by centrifugation at 3,000 g for 30 minutes. Cell pellets were suspended in $1 \mathrm{ml}$ of TE $(10 \mathrm{mM}$ Tris- $\mathrm{HCl}, \mathrm{pH}$ 
8.0 and $50 \mathrm{mM}$ EDTA) buffer, transferred to a $1.5 \mathrm{ml}$ microfuge tube and collected by centrifugation at 3,000 g for 20 minutes. Pelleted cells were re-suspended in $2 \%$ glutaraldehyde in $0.1 \mathrm{M}$ sodium cacodylate buffer $(\mathrm{pH}$ 7.4). Following rinsing in cacocylate ( $\mathrm{pH} 7.4$ ) buffer, the cells were post-fixed in $1 \%$ osmium tetroxide in $0.1 \mathrm{M}$ sodium cacodylate buffer; dehydrated successively in $50 \%, 70 \%, 80 \%, 95 \%, 100 \%$ ethanol and 100\% acetone; and embedded in Spurr's embedding medium [10]. For the final step in embedding, cells suspended in Spurr's were dispensed into Beem capsules (Electron Microscopy Sciences, Hatfield, PA) which were placed in the centrifuge tubes and spun so that pellets were at the tips of the capsules for polymerization. Ultrathin (40-50 nm) sections were made, stained with both uranyl acetate and lead citrate [11] and examined in a FEI Tecnai 12 transmission electron microscope. Images were made with a Megaview III digital camera using analysis software.
As shown in Figure 1A, icosohedral particles were observed outside of and attached to the bacterial cells. Well-defined tails were not apparent, although a faint very short thin structure and resembling a short phage-like tail at a vertex was occasionally observed. The width of these particles was $45.2 \pm 8.5 \mathrm{~nm}(\mathrm{n}=70)$. The isometric morphology and the size of these particles suggested that these particles were putative virions of bacteriohages, probably in the family Podoviridae [12]. Interestingly, TEM images of $X$. fastidosa bacteria published earlier [13] include morphologically similar phage-like particles; however, there was no discussion or interpretation of these. We also observed phage-like particles in X. fastidiosa cells residing in xylem vessels of artificially inoculated almond trees (data not shown).

To further verify the presence of phage particles, we cultured $X$. fastidoisa strain Temecula-1 in $500 \mathrm{ml}$ PW broth for 30 days under the same culture condition as above. A
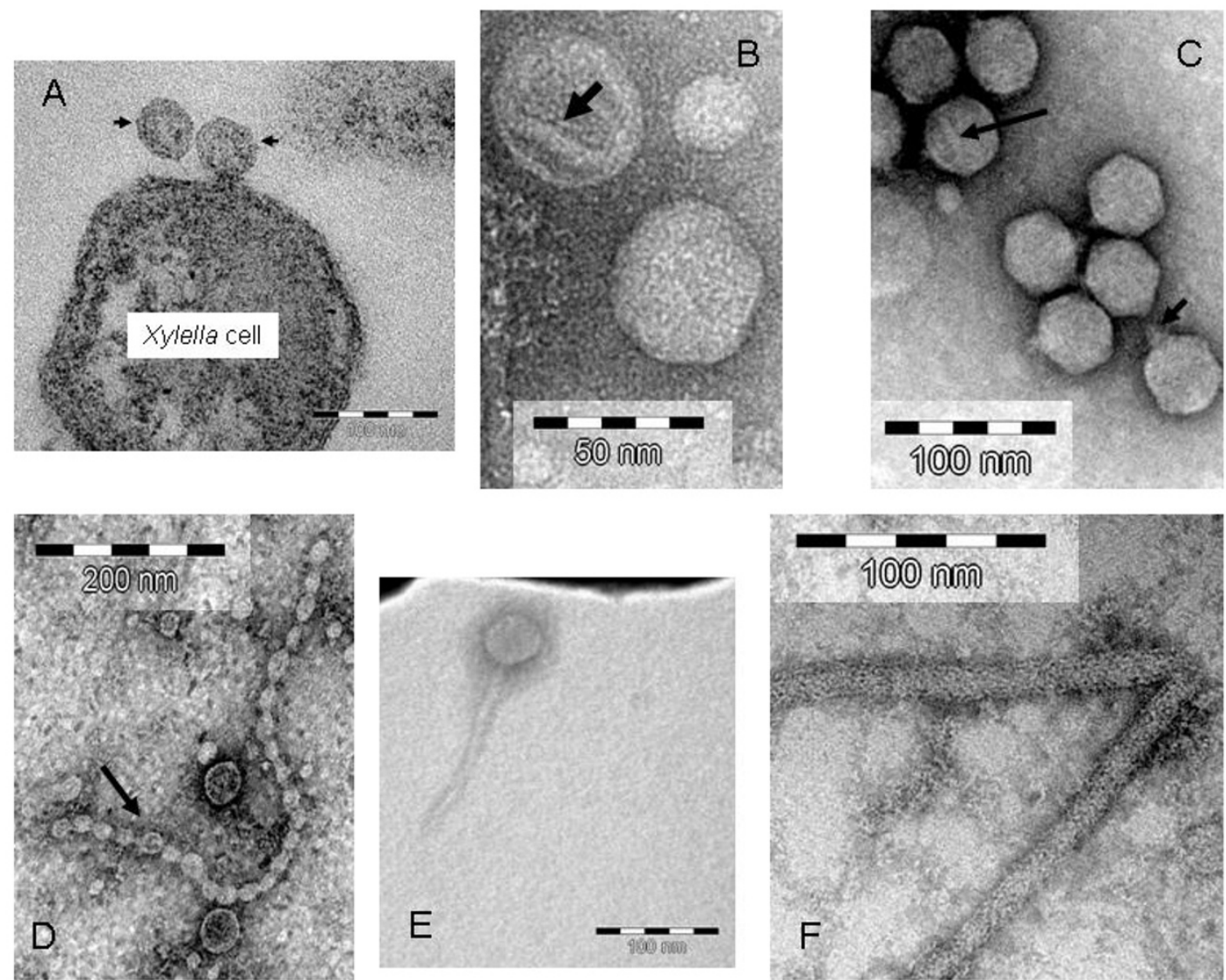

\section{Figure I}

Electron micrographs of: A, Icosahedral phage particles (arrows) associated with a Xylella fastidosa cell; B, Icosahedral phage particles showing a "ridge" on the surface (arrow); C, Particles of phage CP2 from Xanthomonas citri subsp. citri. Long arrow, a surface "ridge" ; Short arrow, a short tail; D, Small type of icosahedral particles in an ordered chain; E, A tailed phage particle. F, Filamentous particles. 
total of 11 batches of cultures were made. Bacterial cells were removed by centrifugation at 5,000 $\mathrm{g}$ for 45 minutes. Supernatants of the bacterial cultures were centrifuged once or twice at $12,000 \mathrm{~g}$. The supernatants were then concentrated by high speed centrifugation $155,000 \mathrm{~g}$ for $1.5-$ 2 hours. The high speed centrifugation pellets were resuspended in 200-500 $\mu$ l sterile distilled water and further purified through equilibrium $\mathrm{CsCl}$ density gradients. The $\mathrm{CsCl}$ density gradients were made up in SM buffer [14]. Briefly, 3-step gradients were 3.4-3.7 ml each of 1.45, 1.5 and $1.7 \mathrm{gm} \mathrm{CsCl} / \mathrm{ml} \mathrm{SM}$ buffer. After layering the resuspended high speed centrifugation pellets $(0.2-1.0 \mathrm{ml})$ on the tops, the gradients were centrifuged at $155,000 \mathrm{~g}$ for 18-21 hours and a presumptive phage particle-containing band was observed (data not shown). After removal of samples from the centrifuged gradients, the $\mathrm{CsCl}$ was removed by extensive dialysis in SM buffer using Slide-ALyzer Mini Dialysis Cassettes per the supplier's (Pierce Biotechnology, Rockland, IL) instructions.

Five $\mu$ l of phage suspension was added to a 400-mesh copper grid and the droplet was partially wicked off using a triangle-shaped piece of $3 \mathrm{M}$ filter paper. The remaining thin layer of liquid was left on the grid after $3 \mathrm{~min}$. Five $\mu \mathrm{l}$ of $2 \%$ uranyl acetate was added to the grid and the droplet partially wicked off after 45 seconds. This procedure was repeated with $5 \mu$ distilled $\mathrm{H}_{2} \mathrm{O}$, and, after immediate partial wicking of the water droplet, the grid was air-dried. The grids were examined by TEM as described above.

Samples collected from $\mathrm{CsCl}$ density gradients revealed the presence of mostly non-tailed icosahedral particles, which could be grouped into two types. The large type particles were about $45 \mathrm{~nm}$ (Fig. 1B), similar to those observed from cell pellets (Fig. 1A). No distinct short tails were observed. "Ridges" were sometimes seen on the particle surface. As a control, we used the same negative staining procedure to prepare bacteriophage CP2 from Xanthomonas citri subsp. citri, a member of the phage family Podoviridae [15]. Short tails were readily recognized in CP2 (Fig. 1C). Particles showing a "ridge" were also observed on these particles, suggesting some structural or morphological similarity between CP2 and the X. fastidosa particles. The small type icosahedral particles were $30.1 \pm$ $5.0 \mathrm{~nm}(\mathrm{n}=20)$ across (Fig. 1D). Interestingly, some of these particles formed an ordered chain (Fig. 1D). Although uncommonly reported, icosahedral phages in ordered chains were observed in ruminal fluid samples of animals [16]. An observed tailed particle is shown in Fig. $1 \mathrm{E}$. The head size was similar to those of the large type of icosahedral particles and the tail was $140 \mathrm{~nm}$ long. In addition, we also observed filamentous particles with a width of $17.2 \pm 0.5 \mathrm{~nm}(\mathrm{n}=10)$ but highly variable in length from 120 to $6,300 \mathrm{~nm}$ (Fig. 1F). We are aware that $X$. fastidosa does not posses flagella [1] but type IV pili was reported [17]. However, available information indicated that the width of type IV pili is 5-7 $\mathrm{nm} \mathrm{[18].}$

In terms of phage morphology, Ackermann [12] summarized all of the known phages into four morphological groups: tailed, polyhedral, filamentous, and pleomorphic, and 20 Families when nucleic acid and other properties were considered. We observed phage-like particles in the tailed, polyhedral, and pleomorhpic morphological groups. However, the low titer of phages under our experimental conditions and the possible contamination of bacterial chromosomal DNA limited our ability to perform further nucleic acid analyses. Enrichment of phage particles from this fastidious bacterium has been highly challenging. Therefore, we are not able to characterize these particles according to the phage family scheme. However, based on morphology, the large icosahedral particles could belong to the Podoviridae but further proof of the presence of short tails is needed; the small icosahedral particles could be in the Microviridae; the tailed particles could be in the Siphoviridae; and the filamentous particles could be in the Inoviridae. Interestingly, all of the four phage families were predicted to be present in $X$. fastidiosa based on prophage sequence analyses [2-6].

We note that the $X$. fastidiosa phages reported here were from late stationary or senescent cultures. This was based on the assumption that prolonged growth in culture would create physical and/or chemical stress to facilitate induction of lysogenic phages into a lytic cycle so that phage particles became visible. We cannot exclude the possibility that some phage particles observed might have been damaged during the preparation process. This could be an explanation of the observed "ridge" formation and the length variation of filamentous particles. Optimization of the phage isolation and purification procedure is needed for future research.

\section{Conclusion}

The presence of different types of phage-like particles resembling those in several bacteriophage families provides new physical evidence, in addition to $X$. fastidiosa genomic information, that $X$. fastidiosa possesses active phages. This is the first report of phage particles released in $X$. fastidiosa cultures.

\section{Competing interests}

The authors declare that they have no competing interests.

\section{Authors' contributions}

JC planned and performed the experiments and prepared the manuscript, EC participated planning the experiments and electron microscopy, and interpreted the data. 


\section{Acknowledgements}

We thank Jeff B. Jones (University of Florida) for providing CP2 phage, and Darlene Hoffmann, Greg Phillips, Don Wade and Rebecca Alvarez for their technical assistance.

\section{References}

I. Wells JM, Raju BC, Hung H-Y, Weisburg WG, Mandelco-Paul L, Brenner BJ: Xylella fastidiosa new-genus new-species gram-negative xylem-limited fastidious plant bacteria related to Xanthomonas-spp. Int J Syst Bacteriol 1987, 37:| 36-| 43.

2. Bhattacharyya A, Stilwagen S, Reznik G, et al.: Draft sequencing and comparative genomics of Xylella fastidiosa strains revea novel biological insights. Genome Res 2002, I 2: I556-I563.

3. Harakava R, Gabriel DW: Genetic differences between two strains of Xylella fastidiosa revealed by suppression subtractive hybridization. Appl Environ Microbiol 2003, 69:1315-1318.

4. Simpson AJ, Reinach FC, Arruda P, Abreu FA, Acencio M, Alvarenga R, Alves LM, Araya JE, Baia GS, Baptista CS, Barros MH, Bonaccorsi ED, Bordin S, Bové JM, Briones MR, Bueno MR, Camargo AA, Camargo LE, Carraro DM, Carrer H, Colauto NB, Colombo C, Costa FF, Costa MC, Costa-Neto CM, Coutinho LL, Cristofani M, DiasNeto E, Docena C, El-Dorry H, Facincani AP, Ferreira AJ, Ferreira VC, Ferro JA, Fraga JS, França SC, Franco MC, Frohme M, Furlan LR, Garnier M, Goldman GH, Goldman MH, Gomes SL, Gruber A, Ho PL, Hoheisel JD, Junqueira ML, Kemper EL, Kitajima JP, Krieger JE, Kuramae EE, Laigret F, Lambais MR, Leite LC, Lemos EG, Lemos MV Lopes SA, Lopes CR, Machado JA, Machado MA, Madeira AM, Madeira HM, Marino CL, Marques MV, Martins EA, Martins EM, Matsukuma AY, Menck CF, Miracca EC, Miyaki CY, Monteriro-Vitorello CB, Moon DH, Nagai MA, Nascimento AL, Netto LE, Nhani A Jr, Nobrega FG, Nunes LR, Oliveira MA, de Oliveira MC, de Oliveira RC, Palmieri DA, Paris A, Peixoto BR, Pereira GA, Pereira HA Jr, Pesquero JB, Quaggio RB, Roberto PG, Rodrigues V, de M, Rosa AJ, de Rosa VE Jr, de Sá RG, Santelli RV, Sawasaki HE, da Silva AC, da Silva AM, da Silva FR, da Silva WA Jr, da Silveira JF, Silvestri ML, Siqueira WJ, de Souza AA, de Souza AP, Terenzi MF, Truffi D, Tsai SM, Tsuhako $M H$, Vallada $H$, Van Sluys MA, Verjovski-Almeida S, Vettore $A L$, Zago MA, Zatz M, Meidanis J, Setubal JC: The genome sequence of the plant pathogen Xylella fastidiosa. Nature 2000 406: $15|-| 57$.

5. Van Sluys MA, de Oliveira MC, Monteiro-Vitorello $C B$, Miyaki $C Y$, Furlan LR, Camargo LE, da Silva AC, Moon DH, Takita MA, Lemos EG, Machado MA, Ferro MI, da Silva FR, Goldman MH, Goldman GH Lemos MV, El-Dorry H, Tsai SM, Carrer H, Carraro DM, de Oliveira RC, Nunes LR, Siqueira WJ, Coutinho LL, Kimura ET, Ferro ES, Harakava R, Kuramae EE, Marino CL, Giglioti E, Abreu IL, Alves LM, do Amaral AM, Baia GS, Blanco SR, Brito MS, Cannavan FS, Celestino AV da Cunha AF, Fenille RC, Ferro JA, Formighieri EF, Kishi LT, Leoni SG, Oliveira AR, Rosa VE Jr, Sassaki FT, Sena JA, de Souza AA, Truffi D, Tsukumo F, Yanai GM, Zaros LG, Civerolo EL, Simpson AJ, Almeida NF Jr, Setubal JC, Kitajima JP: Comparative analyses of the complete genome sequences of Pierce's disease and citrus variegated chlorosis strains of Xylella fastidiosa. J Bacteriol 2003, I 85:1018-1026.

6. Chen J, Civerolo EL, Jarret RL, Van Sluys MA, de Oliveira MC Genetic discovery in Xylella fastidiosa through sequence analysis of selected randomly amplified polymorphic DNAs. Curr Microbiol 2005, 50:78-83.

7. Lauzon CR, Miller TA: A survey of insect vectors of Pierce's disease (PD) and PD-infected plants for the presence of bacteriophage that infect Xylella fastidiosa. In Proceedings of the Pierces Disease Research Symposium San Diego, California; 2001:62. 5-7 December 200I

8. Davis MJ, French WJ, Schaad NW: Axenic culture of the bacteria associated with phony disease of peach and plum leaf scald. Curr Microbiol 1981, 6:309-314.

9. Minsavage GV, Thompson CM, Hopkins DL, Leite RMVBC, Stall RE: Development of a polymerase chain reaction protocol for detection of Xylella fastidiosa in plant tissue. Phytopathology |994, 84:456-46|.

10. Spurr AR: A low viscosity epoxy resin embedding medium for electron microscopy. J Ultrastruct Res 1969, 26:31-43.

II. Venable $\mathrm{JH}$, Coggeshall R: A simplified lead citrate stain for use in electron microscopy. I Cell Biol 1965, 25:407-408.
12. Ackermann HW: 5500 Phages examined in the electron microscope. Arch Virol 2007, I 52:227-243.

13. Kitajima EW, Bakarcic M, Fernandez-Valiela MV: Association of Rickettisalike Bacteria with plum leaf scald disease. Phytopathology 1975, 65:476-479.

14. Sambrook J, Russell DW: Molecular Cloning: A Laboratory Manual. In Cold Spring Harbor Laboratory 3rd edition. Cold Spring Harbor, NY; 200I.

15. Fan FF, Corbett K: Some properties of two bacteriophages of Xanthomonas citri. Phytopathology 1981, 7 I:873.

16. Klieve AV, Bauchop T: Morphological diversity of ruminal bacteriophages from sheep and cattle. Appl Environ Microbiol 1988 , 54:|637-|64|.

17. Meng Y, Li Y, Galvani CD, Hao G, Turner JN, Burr TJ, Hoch HC: Upstream migration of Xylella fastidiosa via pilus-driven twitching motility. J Bacteriol 2005, I 87:5560-7.

18. Mattick JS: Type IV pili and twitching motility. Annu Rev Microbiol 2002, 56:289-314.
Publish with Biomed Central and every scientist can read your work free of charge

"BioMed Central will be the most significant development for disseminating the results of biomedical research in our lifetime. "

Sir Paul Nurse, Cancer Research UK

Your research papers will be:

- available free of charge to the entire biomedical community

- peer reviewed and published immediately upon acceptance

- cited in PubMed and archived on PubMed Central

- yours - you keep the copyright 